\title{
KOMUNIKASI TRANSENDENTAL: SHALAT SEBAGAI BENTUK KOMUNIKASI TRANSENDENT
}

\begin{abstract}
Robeet Thadi*
Abstract

The term transcendental communication is a relatively new field of communication known in the area of communication science studies. Therefore, many interpretations or definitions can be given to transcendental communication. Transcendental communication is vertical, and its form is not as concrete as the form and tradition of communication in general. If in interpersonal communication or group communication for example, the limits of each communication element (communicator, communicant, message, media, etc.) are very clearly visible, with relatively measurable results / effects. While in communication transendental elements of communication is not all can be detected in sensory. Therefore, within certain limits, it is not wrong to say that transcendental communication is private / abstract. To dissect the transcendental communication model, this paper would like to see prayer as a transcendental form of communication that is vertical between God to man or vice versa between man to the creator of Allah SWT.
\end{abstract}

Kata Kunci: shalat, komunikasi vertikal, komunikasi transendent.

\section{Pendahuluan}

Komunikasi sebagai ilmu yang multidisipliner dikembangkan melalui dukungan dari ilmu yang lainnya, demikian dalam mengungkap realitas sebagai objek telaah. Banyak realitas-realitas komunikasi yang harus dipotret dengan cara kerjasama antara ilmu komunikasi dengan ilmu-ilmu lainnya, seperti ilmu sosiologi, antropologi, psikologi, biologi, dan ilmu agama. Realitas tentang hubungan antara manusia dengan Allah SWT (ibadah) misalnya, dapat dianggap sebagai fenomena komunikasi. Namun untuk meneliti hal tersebut tidak tuntas kalau hanya dengan mengandalakan disiplin ilmu komunikasi. Namun hal tersebut dapat dibedah dengan adanya kerjasama antara ilmu komunikasi dengan ilmu agama.

Komunikasi antara Allah SWT dan manusia adalah suatu fenomena komunikasi yang transendental dengan sifatnya yang sangat abstrak, dan tidak dapat diamati secara inderawi. Oleh karena itu dibutuhkan kajian yang komprehensif tentang dimensidimensi transendental dari unsur komunikasi yang ada (terutama manusia sebagai salah satu partisipan komunikasi transendental/spiritual).

Istilah komunikasi transendental merupakan bidang komunikasi yang relatif baru dikenal di wilayah studi ilmu komunikasi. Oleh karena itu, banyak interpretasi atau

* Penulis adalah Dosen Jurusan Dakwah IAIN Bengkulu 
definisi yang bisa diberikan pada komunikasi transendental. Pada tulisan ini sebagai kerangka pemikiran ada beberapa perspektif yang setidaknya memberikan definisi yang berbeda tentang komunikasi transendental, setidaknya akan memperkaya cakrawala kita tentang apa itu komunikasi transendental.

Dalam perspektif filsafat Islam, komunikasi transendental diartikan sebagai komunikasi antara hamba dengan sesuatu yang supranatural yang berpusat pada qalb. PerspektifAntropologi Metafisik memaknai komunikasi transendental sebagai komunikasi dengan sesuatu yang 'esensi', sesuatu yang 'ada' di balik 'eksistensi.' Berdasarkan berbagai perspektif tersebut, menurut Prof.Nina Syam, ${ }^{1}$ bahwa komunikasi transendental adalah komunikasi yang berlangsung di dalam diri, dengan sesuatu "di luar diri" yang disadari keberadaannya oleh individu (tersebut).

Komunikasi yangmelibatkan manusia dengan Tuhannya itulah yang sering disebut komunikasi transendental. ${ }^{2}$ Manusia merupakan makhluk sosial yang tidak dapat berdiri sendiri, ia membutuhkan orang lain untukmempertahankan eksistensinya. Manusia harus membangun hubungan horisontal yakni dengan manusia lainnya dan vertikal dengan Tuhannya. Hubungan itu akan membawa seorang individu menjadi manusia paripurna.
Hubungan dialektis antara dimensi vertikal dan horizontal dapat dijelaskan pula dengan melihat tiga perspektif transendental yaitu penerimaan, respons dan reaksi. Tiga istilah ini merujuk pada sisi kemanusiaan daripernyataan Ilahi yaitu bahwa manusia melakukan reaksi atas komunikasi dengan dirinya yang telah menerima pesan Tuhan. Jadi dalam perspektif penerimaan manusia dicari Tuhan.

Dalam perspektif respons manusia mencari Tuhan, misalnya dalam bentuk doa. Doa dapat dipahami sebagai dialog intrapersonal dengan diri sendiri, di mana misteri diri secara intuitif dialami sebagai tanda komitmen kepada Tuhan. ${ }^{3}$ Aspek Vertikal dari komunikasi yang menunjukkan bahwa individu pada akhirnya terhubung dengan pencipta sebagai sumber dari adanya dan bahwa hubungan itu merupakan dasar dari diri sebagai individu. ${ }^{4}$ Berhubungan dengan Allah atau Tuhan merupakan kebutuhan dasar yang menjadikan seorang individu merasa ada dan berarti.

Dalam Islam, hubungan manusia dengan Tuhannya dibangun melalui shalat, zikir, doa serta melalui ibadah-ibadah lain yang tujuannya untuk mendekatkan diri kepada Tuhannya seperti melaksanakan ibadah haji. ${ }^{4}$ Melalui doa, manusia dapat melakukan komunikasi dengan Allah tanpa hijab, tanpa tabir duniawi dan ragawi yang menghalangi. 
Pada saat seseorang sedang berdoa dengan khusyuk, terjadi proses transformasi kefanaan dan secara substansial.

Aplikasi yang sesungguhnya dari komunikasi transendental adalah pada saat kita mendirikan shalat, berdzikir dan berdoa. Shalat pada dasarnya adalah saat di mana manusia berkomunikasi langsung dengan Allah SWT. Pada saat itu sebenamya tidak ada pembatas antara manusia dengan Allah SWT. Komunikasi langsung terjadi asal kita benar-benar punya keyakinan yang kuat bahwa Allah ada di hadapan kita sedang memperhatikan dan mendengar doa kita.Takbr, ruku, dan sujud adalah bentuk tawadhlu lita pada-Nya, memasrahkan seluruh jiwa dan raga kita pada Allah SWT.

Berdasarkan uraian di atas (terutama komunikasi transendental, maka komunikasi transendental bersifat vertikal, dan wujudnya pun tidak se-kongkrit bentuk dan tradisi komunikasi pada umumnya. Kalau dalam komunikasi interpersonal atau komunikasi kelompok misalnya, batasan masing-masing unsur komunikasi (komunikator, komunikan, pesan, media, dll) sangat jelas terlihat, dengan hasil/efek yang relatif dapat diukur/diketahui. Sedangkan dalam komunikasi transendental unsur-unsur komunikasinya tidak semua dapat dideteksi secara inderawi. Oleh karena itu, dalam batas-batas tertentu, tidaklah salah apabila dikatakan bahwa komunikasi transendental bersifat private/ abstrak. Untuk membedah model komunikasi transendental, tulisan ini ingin melihat sholat sebagai bentuk komunikasi transcendental yang bersifat vertical antara Allah kepada manusia atau sebaliknya antara manusia kepada penciptanya Allah SWT.

\section{Sholat dalam Konteks Komunikasi Transendental}

Dalam konteks Komunikasi Transendental, pesan (perintah) shalat dari Allah, disampaikan dengan cara yang berbeda kepada nabi Muhammad SAW dan kepada manusia. Kalau dalam menyampaikan pesan shalat kepada nabi Muhammad SAW, Allah SWT melakukannya lewat 'komunikasi interpersonal'. Sedangkan pesan shalat kepada manusia disampaikan secara tidak langsung lewat 'media' atau firmannya dalam kitab suci Al-Qur'an.

Ayat-ayat Al-Qur'an yang berbicara tentang shalat, tersebar dalam 92 ayat AlQur'an. Namun terdapat beberapa ayat yang secara langsung (eksplisit) berbicara tentang perintah (pesan) Allah untuk melaksanakan shalat. Di antara ayat-ayat tersebut adalah: Surat Al-Baqarah ayat 43: Dan dirikanlah shalat, tunaikanlah zakat dan rukuklah beserta orang-orang yang rukuk. ${ }^{5}$ Surat Huud ayat 114: Dan dirikanlah shalat itu pada kedua tepi siang (pagi dan petang) dan pada 
bahagian permulaan daripada malam. Sesungguhnya perbuatan-perbuatan yang baik itu menghapuskan (dosa) perbuatanperbuatan yang buruk. Itulah peringatan bagi orang-orang yang ingat. ${ }^{6}$ Surat Ibrahim ayat 31: Katakanlah kepada hamba-hamba-Ku yang telah beriman: "Hendaklah mereka mendirikan shalat, menafkahkan sebahagian rezeki yang Kami berikan kepada mereka secara sembunyi atau pun terang-terangan sebelum datang hari (kiamat) yang pada hari itu tidak ada jual beli dan persahabatan. $^{7}$

Beberapa ayat di atas memperlihat adanya pesan komunikasi transendental dari Allah kepada manusia tentang ibadah shalat. Proses penyampaian pesan tersebut tidak secara langsung, namun melalui nabi Muhammad SAW dan lewat 'media' AlQur'an. Dengan demikian, proses komunikasi Allah kepada manusia untuk menyampaikan pesan shalat menggunakan two step communication (komunikasi dua tahap).

\section{Respon Manusia terhadap Pesan Allah}

Dalam konteks two step communication antara Allah dengan manusia, Al-Qur'an merupakan wujud pesan (komunikasi) Allah kepada manusia. Dalam hal ini, Allah adalah komunikatornya, AlQur'an adalah medianya, sedangkan manusia adalah komunikannya. Sebagai komunikan yang telah dibekali dengan iman dan ilmu, manusia tentunya meyakini, membaca dan memahami isi pesan Allah tersebut (AlQur'an). Setelah memahami isi pesan Allah SWT, manusia memberikan respon (feedback) dalam bentuk ucapan dan sikap. Perintah shalat yang dianjurkan Allah SWT lewat media-Nya Al-Qur'an, direspon dengan melaksanakan shalat oleh manusia. Dengan demikian, shalat dalam perspektif komunikasi transendental merupakan bentuk feedback manusia terhadap pesan (perintah) yang telah diberikan oleh Allah kepada mereka.

Semua pesan Allah SWT tentang shalat dalam Al Qur'an masih bersifat umum, dan tidak merinci secara operasional bagaimana shalat dilaksanakan. Oleh karena fungsi komunikasi tahap kedua (komunikasi dari Nabi Muhammad SAW kepada manusia/pengikutnya). Dalam beberapa hadits yang telah diriwayatkan, Rasulullah Muhammad SAW memberikan petunjuk teknis tentang shalat. Di samping itu, shalatshalat yang dilakukan oleh Nabi Muhammad SAW merupakan contoh yang harus diikuti oleh pengikutnya. Beliau bersabda: "Shalatlah kamu sebagaimana engkau melihat saya shalat"(Hadis)

Meskipun berpedoman pada ayat yang sama dan ada contoh dari Nabi yang 
sama (Muhammad SAW), namun dalam prakteknya, shalat yang dikerjakan oleh umat Islam dilaksanakan dengan cara yang berbeda (meskipun esensi shalat mereka sama). Perbedaan tersebut minimal terlihat dari komunikasi verbal (bacaan shalat) dan komunikasi nonverbal (gerakan shalat) yang masing-masing orang kerjakan. Pada titik inilah wilayah private-nya komunikasi transendental (komunikasi antara manusia denganAllah).

\section{Komunikasi Verbal dan Nonverbal dalam Shalat}

Dalam ibadah shalat yang dilakukan oleh hamba Allah, berlangsung dua komunikasi sekaligus, yaitu komunikasi verbal dan komunikasi nonverbal. Berikut akan dijelaskan bagaimana proses dan makna kedua jenis komunikasi tersebut dalam ibadah shalat.

\section{Komunikasi Verbal}

Shalat yang dilakukan oleh seorang hamba dimaknai sebagai aktivitas dialog antara manusia dengan Allah (komunikasi transendental atau komunikasi transendental). Nabi Muhammad SAW sendiri mempertegas hal tersebut dalam sabdanya, dengan artinya sebagai berikut:

Sesungguhnya seorang kamu apabila ia sedang shalat, ia hanya berbisik dengan Tuhannya. Oleh karena itu hendaklah ia perhatikan, bagaimana ia berbisik denganNya (HR. Hakim)

Dalam hadis yang lain, diriwayatkan oleh H.R. Bukhari dan Muslim, Rasulullah SAW bersabda, yang artinya sebagai berikut: Sesungguhnya seseorang kamu, apabila ia sedang shalat, maka sesungguhnya ia sedang berbisik dengan Tuhannya. Oleh sebab itu janganlah ia meludah kehadapannya dan jangan pula ke kanannya, tetapi meludahlah ke kirinya dan ke bawah tapak kakinya. (H.R. Bukhari dan Muslim)

Komunikasi verbal (lisan) manusia dengan Allah SWT saat shalat, dimulai dengan kalimat pengakuan akan kebesaran Allah SWT (Allah Akbar). Kalimat yang sama juga diucapkan pada setiap pergantian pergerakan dalam shalat. Hal ini oleh beberapa ulama diartikan mengandung makna bahwa pengakuan akan kebesaran Allah SWT pada awal shalat akan membuat orang yang shalat untuk berkonsentrasi dengan menyingkirkan 'tuhan-tuhan dunia' yang kecil.

Menurut Khalili bahwa rahasia dari mengangkat kedua tangan tatkala mengucapkan takbir (Allahu Akbar) adalah menafikan seluruh perkara duniawi serta kekuatan semu dan palsu, juga menafikan berbagai sifat materi dari-Nya. ${ }^{8}$ 
Telah berfirman Allah ‘Azza wa Jalla: Aku bagi shalat itu antar-Ku dan hamba-Ku menjadi dua bagian dan bagi hamba-Ku apa yang dimintanya. Apabila si hamba membaca: Segala puji bagi Allah, Tuhan sekalian alam, Allah menjawab: Hamba-Ku telah memuji Aku. Apabila si hamba membaca: Yang pengasih lagi penyayang, Allah menjawab: Hamba-Ku telah memuliakan Aku. Apabila si hamba membaca: Engkau saja yang kami sembah dan Engkau saja yang kami mintai pertolongan,Allah menjawab: Ini seperdua untuk-Ku dan seperdua lagi untuk hamba-Ku dan bagi hambaku apa yang dimintanya. Apabila si hamba membaca: Kami mohon ditunjuki jalan yang lurus, yaitu jalan orang-orang yang telah Engkau beri nikmat atas mereka, bukan jalan orang-orang yang sesat, Allah menjawab: Ini semua untuk hamba-Ku dan bagi hamba-Ku apa yang dimintanya (HR. Muslim).

\section{Komunikasi Nonverbal}

Shalat sebagai ibadah wajib bagi umat Islam, selain mengandung unsur komunikasi transendental verbal, juga sarat dengan pesan-pesan nonverbal berupa gerakangerakan simbol yang relevan dengan perintah Allah SWT. Gerakan-gerakan shalat sendiri (sebagai bentuk komunikasi transendental nonverbal), bukan suatu gerakan yang hampa akan tujuan dan makna filosofis. Berikut akan dijelaskan beberapa makna di balik simbolsimbol nonverbal dalam ibadah shalat.

\section{Makna Rukuk}

$$
\text { Emha Ainun Nadjib, }{ }^{10}
$$

mendeskripsikan makna-makna simbol nonverbal yang dilakukan dalam ibadah shalat. Gerakan rukuk menurutnya, dapat diartikan sebagai anjuran Allah untuk menjinakkan segala sifat 'kebinatangan' (khususnya sifat yang jelek dari binatang) yang melekat dalam diri setiap orang yang shalat, karena posisi manusia yang sedang ruku' menyerupai bentuk fisik binatang pada umumnya, seperti kambing, kerbau, sapi, kucing, anjing, dan beberapa binatang serupa lainnya.

Makna lain dari rukuk dikemukakan oleh Khalili. ${ }^{11}$ Menurut dia bahwa tatkala seseorang yang shalat membungkukkan tubuh dan melakukan rukuk, pada kakekatnya ia mengakui kehinaan dan kerendahan dirinya, dan dengan mengucapkan zikir rukuk, ia juga mengakui kebesaran dan keagungan Allah SWT. Dan ini merupakan sebaik-baik bentuk kerendahan diri seorang hamba di hadapan keagungan Al Haqq. Allah SWT memuliakan setiap hambaNya yang senantiasa merendahkan diri di hadapan-Nya. Hal ini perkuat oleh suatu riwayat dari Imam Hasan al Askari dalam kitab Biharul Anwar, juz 82 sebagai berikut: 
"Tatkala orang yang shalat melakukan rukuk, maka Allah SWT menyeru para malaikat dan berfirman, 'wahai para malaikat$K u$, tidaklah kalian menyaksikan hamba yang tengah melakukan shalat, bagaimana ia merendahkan diri di hadapan kebesaran dan keagungan-Ku? Kalian sebagai saksi, Aku akan membesarkannya di rumah keagungan dan kebesaran-Ku”

\section{Makna Sujud}

Dalam Al-Qur'an, Allah SWT beberapa kali menganjurkan hambaNya untuk sujud. Perintah bersujud dalam Al Qur'an dianjurkan dalam berbagai konteks, seperti sujudnya malaikat pada Adam, sujudnya seluruh alam, sujudnya manusia, dan konteks lainnya. Berikut beberapa ayat yang berbicara tentang sujud: SuratAli Imran ayat 43: Hai Maryam, taatlah kepada Tuhanmu, ${ }^{12}$ sujud dan rukuklah bersama orang-orang yang rukuk. Surat An Najm ayat 62: Maka bersujudlah kepada Allah dan sembahlah (Dia). ${ }^{13}$

Sujud adalah menundukkan kepala ke hadirat Tuhan Yang Maha Suci, meletakkan kepala di atas tanah, dan menganggap diri hina. Roh dan jiwa sujud adalah melepaskan hati dari belenggu berbagai perkara material dan fana, serta memutus ketergantungan pada keduniawian.
Hakekat sujud adalah menjalin hubungan dengan sang sesembahan serta mencapai makam yang terpuji. Sujud adalah keadaan dimana hamba amat dekat dengan Tuhannya. Gerakan (posisi) sujud juga memiliki makna filosofis tertentu. Salah satu maknanya adalah sebagai simbol kekecilan dan ketidakberdayaan kita dihadapan Allah SWT yang Maha Besar dan Maha Perkasa. Sujud dapat dimaknai sebagai wujud pengingatan jiwa akan asal-muasal dan tempat kembali (tanah).

Makna lain dari sujud adalah sebagai simbol kehinaan dan ketidaberdayaan manusia di hadapan Allah Yang Maha Besar. Kepala yang menjadi simbol kehormatan dan kewibawaan manusia, pada saat sujud ditempatkan pada tempat yang paling bawah, yaitu tanah yang sehari-hari kita injak. Padahal dalam aktivitas sehari-hari (di luar ibadah shalat), kepala adalah organ tubuh yang selalu kita jaga dan hormati. Orang yang normal akan marah apabila kepalanya dipukul. Dan dianggap biasa saja apabila organ tubuh yang lain diperlakukan dengan cara yang sama (dipukul).

Dengan makna tersebut di atas, maka orang yang shalat tidaklah sepantasnya untuk bersikap sombong (baik terhadap sesama manusia, lebih-lebih terhadap Allah SWT), karena manusia sangat rendah dan tidak memiliki daya apa-apa di hadapan 
Allah. Allah SWT banyak sekali melarang manusia untuk berlaku sombong. Beberapa ayat-Nya banyak berbicara tentang sombong. Dua di antaranya, dapat dikutip sebagai berikut: Dan janganlah kamu berjalan di muka bumi ini dengan sombong, karena sesungguhnya kamu sekali-kali tidak dapat menembus bumi dan sekali-kali kamu tidak akan sampai setinggi gunung, (Q.S: Al Israa':37). ${ }^{14}$ Dan janganlah kamu memalingkan mukamu dari manusia (karena sombong) dan janganlah kamu berjalan di muka bumi dengan angkuh. Sesungguhnya Allah tidak menyukai orang-orang yang sombong lagi membanggakan diri (Q.S. Lukman:18). ${ }^{15}$

\section{Penutup}

Penjelasan tentang shalat sebagai salah satu bentuk Komunikasi Transendental (komunikasi antara Allah SWT dan manusia) di atas, menegaskan bahwa proses komunikasi yang berlangsung antara Allah SWT kepada manusia dan manusia Kepala Allah berlangsung secara vertikal bersifat private dan abstrak. Shalat yang dilakukan dengan dzikir dan doa akan sangat membantu menenangkan hati, jiwa dan raga kita sehingga gerak langkah kita hidup di dunia adalah atas dasar tutunan-Nya. Kita harus yakin bahwa tutuntan dan perlindungan Allah SWT dapat membuat hidup kita penuh makna untuk bekal di dunia dan akhirat sebagai perwujudan dari komunikasi transendental yang effektif. Sebagai sebuah aktivitas dalam komunikasi transendental, pada tataran aplikasinya sebagai bentuk dari two step communication yang bersifat vertikal sebagai sebuah aktivitas berupa komunikasi verbal dan komunikasi nonverbal yang sarat makna.

\section{Endnote}

${ }^{1}$ Nina Winangsih Syam dan Dadang Sugiana, Perencanaan Pesan dan Media, (Jakarta: Universitas Terbuka, 2004), hal. 14

${ }^{2}$ Deddy Mulyana, Nuansa-Nuansa Komunikasi; Meneropong Politik Dan BudayaKomunikasi Masyarakat Kontemporer (Remaja Rosdakarya, Bandung: 1999) h. 49

${ }^{3}$ Rijardus A.Van Koiij, dkk., Menguak Fakta Menata Karya Nyata (Jakarta: GunungMulia, 2008), h.101.

${ }^{4}$ A. Sudiarja, dkk., Karya Lengkap Driyarkara: Esai-Esai Filsafat Pemikir YangTerlibat Penuh Dalam Perjuangan Bangsanya (Jakarta: Gramedia Pustaka Utama, 2006), h.687.

${ }^{5}$ Al-Qur'an dan Terjemahannya, Surat AlBaqarah ayat 43

${ }^{6}$ Al-Qur'an dan Terjemahannya, Surat Huud ayat 114

${ }^{7}$ Al-Qur'an dan Terjemahannya, Surat Ibrahim ayat 31

${ }^{8}$ Musthafa Khalili, Berjumpa Allah dalam Shalat, (Jakarta: Zhara, 2004), hal. 87

${ }^{9}$ Al-Qur'an dan Terjemahannya, Surat AlBaqarah ayat 110

${ }^{10}$ Dalam Jawa Pos, 1997

${ }^{11}$ Musthafa Khalili, Berjumpa Allah dalam Shalat, (Jakarta: Zhara, 2004), hal. 95

${ }^{12}$ Al-Qur'an dan Terjemahannya, Surat Ali Imran ayat 43

${ }^{13}$ Al-Qur'an dan Terjemahannya, Surat An Najm ayat 62

${ }^{14}$ Al-Qur'an dan Terjemahannya, Surat Israa' ayat 37

${ }^{15}$ Al-Qur'an dan Terjemahannya, Surat Lukman ayat 18 